\title{
Therapeutic exercises for the control of temporomandibular disorders
}

\author{
Alberto da Rocha Moraes¹, Monique Lalue Sanches¹, Eduardo Cotecchia Ribeiro², Antonio Sérgio Guimarães ${ }^{3}$
}

Introduction: Temporomandibular disorder (TMD) is a multifactorial disease. For this reason, it is difficult to obtain an accurate and correct diagnosis. In this context, conservative treatments, including therapeutic exercises classified as stretching, relaxation, coordination, strengthening and endurance, are oftentimes prescribed. Objective: Thus, the aim of the present article was to conduct a literature review concerning the types of exercises available and the efficacy for the treatment of muscular TMD. Methods: The review included researches carried out between 2000 and 2010, indexed on Web of Science, PubMed, LILACS and BBO. Moreover, the following keywords were used: Exercise, physical therapy, facial pain, myofascial pain syndrome, and temporomandibular joint dysfunction syndrome. Studies that did not consider the subject "TMD and exercises", used post-surgery exercises and did not use validated criteria for the diagnosis of TMD (RDC/TMD) were not included. Results: The results comprised seven articles which proved therapeutic exercises to be effective for the treatment of muscular TMD. However, these studies are seen as limited, since therapeutic exercises were not applied alone, but in association with other conservative procedures. In addition, they present some drawbacks such as: Small samples, lack of control group and no detailed exercise description which should have included intensity, repetition, frequency and duration. Conclusion: Although therapeutic exercises are considered effective in the management of muscular TMD, the development of randomized clinical trials is necessary, since many existing studies are still based on the clinical experience of professionals.

Keywords: Temporomandibular joint dysfunction syndrome. Myofascial pain syndromes. Physical therapy modalities. Exercise.

Introdução: a disfunção temporomandibular (DTM) é uma doença multifatorial, geralmente com evolução benigna. Por esse motivo, é difícil a obtenção de um diagnóstico inicial preciso e correto, levando a um consenso na prescrição de tratamentos conservadores, entre eles, os exercícios terapêuticos, que são classificados em exercícios de alongamento, relaxamento, coordenação, fortalecimento e resistência. Objetivo: o objetivo desse estudo foi realizar uma revisão de literatura dos trabalhos que apresentam os tipos de exercícios disponíveis e sua eficácia para o tratamento das DTM musculares. Métodos: foi feito um levantamento bibliográfico, de 2000 a 2010, nas bases se dados Web of Science, PubMed, LILACS e BBO, cruzando os seguintes descritores: exercise, physical therapy, facial pain, myofascial pain syndrome e temporomandibular joint disfunction syndrome. Foram excluídos os trabalhos que não consideravam o tema exercícios e DTM, utilizavam exercícios pós-cirúrgicos e que não utilizavam critérios validados para o diagnóstico da DTM (RDC/TMD). Resultados: resultaram sete artigos, que mostraram que os exercícios terapêuticos foram efetivos para o tratamento de DTM muscular. No entanto, uma das limitações desses estudos foi a não utilização exclusiva dos exercícios durante o tratamento, mas sim sua associação com outros procedimentos conservadores. Outras dificuldades apresentadas foram as amostras pequenas, a falta de grupo controle e a não descrição minuciosa da realização do exercício quanto à intensidade, número de repetições, frequência e duração. Conclusão: apesar dos exercícios terapêuticos apresentarem eficácia no controle da DTM muscular, é necessário o desenvolvimento de ensaios clínicos randomizados sobre o assunto, pois, muitos dos trabalhos existentes ainda são baseados na experiência clínica do profissional.

Palavras-chave: Síndrome da disfunção da articulação temporomandibular. Síndromes da dor miofascial.

Modalidades de fisioterapia. Exercício.

${ }^{1}$ Specialist in TMD and Orofacial pain, UNIFESP.

${ }^{2} \mathrm{PhD}$ in Anatomy and Associate Professor at the Morphology and Genetics Department, UNIFESP.

${ }^{3} \mathrm{PhD}$ in Morphology, UNIFESP.
How to cite this article: Moraes AR, Sanches ML, Ribeiro EC, Guimarães AS. Therapeutic exercises for the control of temporomandibular disorders. Dental Press J Orthod. 2013 Sept-Oct;18(5):134-9.

Submitted: April 19, 2011 - Revised and accepted: December 03, 2011

" The authors report no commercial, proprietary or financial interest in the products or companies described in this article.

Contact address: Monique Lalue Sanches

Rua Pereira da Nóbrega, 324 - Apto 43 - São Paulo/SP - Brazil

CEP: 01.549-020 -E-mail: moniquelsanches@uol.com.br 


\section{INTRODUCTION}

Temporomandibular disorder (TMD) is a collective term that covers a broad spectrum of clinical problems of the temporomandibular joint (TMJ), masticatory muscles and associated structures. It is mainly characterized by pain, joint sounds and irregular or limited mandibular function. ${ }^{1,2}$ It is most prevalent in females aged between 20 and 45 years old $^{3}$ and it is subdivided by the American Academy of Orofacial Pain (AAOP) into muscular TMD and articular TMD; with the muscular type being much more prevalent, although it is possible for both to occur concomitantly. ${ }^{1}$ TMD classification is based on different forms and methods. The classification developed by Dworkin et al, named as Research Diagnostic Criteria for Temporomandibular Disorder (RDC/TMD) ${ }^{4}$ is one of the most used.

TMD has no specific etiological factor, however risk factors that affect the dynamic balance of the masticatory system have been identified. These risk factors are divided into traumatic, anatomical, physiopathological and psychosocial. ${ }^{1,3}$ For this reason, and for having a benign course, ${ }^{5}$ it often becomes difficult to obtain definite, accurate and correct diagnosis. Additionally, conservative, reversible treatment is oftentimes prescribed, since the majority of TMDs are of muscular origin. ${ }^{6-10}$ Treatment includes heat or cold therapy, cognitive-behavioral therapy, use of intraoral appliances and different types of physical exercises. However, current evidence of the effectiveness of physical exercises is poor due to a limited number of appropriate randomized clinical trials. ${ }^{11}$ Nevertheless, recent articles conducted under elaborated criteria have shown the real effects of this type of treatment, which corroborates their effectiveness. ${ }^{5.6,7,9,10,12,13,14}$ Exercise is the first treatment choice for patients with muscular TMD, since it presents low cost and good effectiveness, ${ }^{9,15}$ in addition to having the same prognosis of treatment performed with oral stabilization appliances. ${ }^{12,14}$

In order to analyze the effectiveness as well as the different types of exercises available for the treatment of muscular TMD, a literature review was carried out. The review included researches conducted between 2000 and 2010, indexed on Web of Science, PubMed, LILACS and BBO. Additionally, the following keywords were used: Exercise, physical therapy, facial pain, myofascial pain syndrome, and temporomandibular joint dysfunction syndrome. In selecting the sample, the following inclusion criteria were applied: Articles addressing not only diagnosis of muscular TMD by means of validated criteria (RDC/TMD), but also the use of therapeutic exercises for its treatment. Studies that did not consider the subject "exercises and TMD", used postsurgery exercises and were in a language other than Portuguese or English were excluded. Based on this information, the goal of this study was to present, through a review, the modalities of exercises available for the treatment of muscular TMD. The effectiveness of such exercises was assessed as well.

Therapeutic exercises are intended to perform muscle contractions and body movements in order to improve the overall function of individuals. Additionally, they aim at helping patients to find out the real necessity of exercises in their daily routine. This includes exercise positive and progressive performance as well as adjustment in terms of the type and amount of appropriate forces applied to the body system, aiming at treating the deficiency by improving musculoskeletal function and maintaining well-being. ${ }^{9}$

Exercises used for the treatment of muscular TMD are intended to reduce pain, improve coordination of masticatory muscles, reduce muscle spasm and hyperactivity, restore the original muscle length, strengthen the muscles involved, and promote tissue repair and regeneration. ${ }^{6,9,16-20}$

\section{TYPES OF EXERCISES}

\section{Stretching and relaxation}

This type of exercise aims to decrease tension of the muscle fibers. ${ }^{10}$ It can be performed passively, when there is help for achieving the desired movement, or in an active way, when the movement is performed without any assistance. ${ }^{18}$ These exercises are recommended when motion range is limited and pain is present. ${ }^{1,18,19,21}$ The elevator jaw muscles are stretched when the jaw moves downwards (opening the mouth). ${ }^{8}, 9$ This is considered an isotonic exercise because it presents dynamic muscle work, with rhythmic alternation between contraction and relaxation. ${ }^{22}$

Muscles can also be stretched by means of the reciprocal inhibition technique in which opposing mus- 
cles are contracted isometrically (counter-resistance force), actively assisting the movement of stretching and consequent relaxation of the muscle. ${ }^{12,23}$

The contraction-relaxation technique, also used to stretch shortened muscle fibers, is the contraction of a strained muscle followed by its relaxation, which allows passive stretching of this muscle. ${ }^{16,23}$

One of the exercises frequently used to promote relaxation and stretching of the elevator jaw muscles involves opening and closing the mouth slowly, with the apex of the tongue positioned on the lingual surface of the maxillary incisors (pronunciation of the letter "N"). ${ }^{10}$ Pronouncing the letter " $\mathrm{N}$ " several times a day and keeping the tongue in this position, with lips closed, also promotes muscular relaxation. ${ }^{9,19}$

This technique must be performed several times a day in order to assure its effectiveness. ${ }^{10}$

\section{Coordination exercises}

Elevation and depression movements of the jaw are performed bilaterally, symmetrically and with equal intensity. When this does not occur, it results in movement incoordination. Many times, besides causing limited range of motion and pain, TMD also causes incoordination of jaw movements, thus causing joint sounds. ${ }^{21}$

The therapy that promotes coordination of the muscles involved in the movements cited above includes exercises of opening and closing the mouth slowly in front of a mirror with a straight vertical line drawn, with the patient trying to keep the midline of the lower dental arch parallel to the mirror during the execution of movements. ${ }^{8,17,24}$ This same exercise is also performed by placing right and left index fingers in the lateral pole region of the mandibular condyle, with the purpose of assisting movement coordination. ${ }^{3,9}$ Twenty repetitions of this exercise, three times a day, are recommended.

Another way to promote coordination of masticatory muscles is to exercise a resisted isometric contraction of low intensity in the opposite direction of the movement performed. ${ }^{25}$

\section{Strengthening and endurance exercises}

Muscular strength is mainly achieved by isometric exercises, although it can also be obtained by isotonic (concentric and eccentric) ${ }^{24}$ and isokinetic ${ }^{22}$ exercises. Isometric exercises promote muscular contraction without the occurrence of adjacent joint movement, thus, it is considered a static muscle exercise. ${ }^{22}$

Isometric exercises for the masticatory muscles are performed by applying a counter-resistant force to the movement being performed. ${ }^{16}$ Forcefully placing the chin on a closed hand during depression jaw movement (mouth opening), and hindering its elevation (closing) by pressing the inferior incisors with the index and middle fingers are considered muscular strengthening exercises that depress and elevate the jaw, respectively. In lateral jaw movements, the counter-resistance force is applied by means of pressing the lateral area of the mandibular body with the index and middle fingers, exerting a force opposite to the movement performed. These exercises should be repeated several times a day. An excessive counter-resistance force should not be applied, in which case reciprocal inhibition would occur, ${ }^{25}$ causing loss of exercise function; that is, it would cease to be an exercise for strengthening and become an exercise for relaxation.

\section{RESULTS}

Results are shown in Table 1.

\section{DISCUSSION}

The model of chronic pain used to give insight into the etiology, maintenance, and management of TMD comprises a mixture of biological factors embedded in a matrix of psychological and psychosocial factors that produce a sensation of pain which is unique and specific to each individual. Therefore, no isolated factor contributes to the understanding of how clinicians decide on treatment options or how patients respond to long-term treatment, ${ }^{7}$ which results in a variety of studies with very different outcomes. ${ }^{10,13,18,19}$ Individuals who report pain and functional limitation, oral parafunctional habits, pain in other regions of the body and disease summarization present TMD of greater severity and longer duration. ${ }^{26}$

Prescription of exercises as the treatment of choice requires not only knowledge of the anatomy of the muscles with regard to their shape, type, function and location (fixed attachment and mobile attachment), 
but also knowledge of the biomechanics of the affected joint. With that in mind, it is possible to develop and prescribe an unlimited number of exercises.

Exercises for stretching and relaxation are prescribed as a first-choice therapy when painful symptomatology is present. Basically, they are aimed to decrease pain by means of increasing local circulation. They also work to improve flexibility and range of

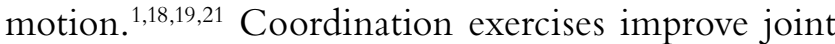
muscle function, mobility and biomechanics, reestablishing synchronism of jaw movements. Such exercises comprise mouth-opening and mouth-closing isotonic exercises. ${ }^{8,17,24}$ On the other hand, strengthening and endurance exercises hinder relapse of TMD and are performed through isometric exercises along with the application of a light counter-resistant force.

Table 1 - Studies concerning the achievement of therapeutic exercise in the treatment of muscular TMD classified by diagnostic criteria of RDC/TMD, combined with other therapeutic techniques or alone.

\begin{tabular}{|c|c|c|c|c|}
\hline Year/author & Title & n & Treatment & Result (*) \\
\hline $\begin{array}{l}\text { Carlson et a }{ }^{15} \\
2001\end{array}$ & $\begin{array}{l}\text { Physical self-regulation } \\
\text { training for the management } \\
\text { of temporomandibular } \\
\text { disorders }\end{array}$ & 44 & $\begin{array}{l}\text { G1 - oral appliance } \\
\text { G2 - postural relaxation, } \\
\text { diaphragmatic breathing, } \\
\text { proprioceptive re-education }\end{array}$ & $\begin{array}{c}\text { G2 was more effective } \\
\text { than G1 }\end{array}$ \\
\hline $\begin{array}{c}\text { Dworkin et } \mathrm{al}^{7} \\
2002\end{array}$ & $\begin{array}{l}\text { A randomized clinical trial } \\
\text { of a tailored comprehensive } \\
\text { care treatment program for } \\
\text { temporomandibular disorders }\end{array}$ & 117 & $\begin{array}{l}\text { G1 - stretching, coordination } \\
\text { exercise, medication, oral } \\
\text { appliance } \\
\text { G2 - stretching, postural } \\
\text { relaxation, diaphragmatic } \\
\text { breathing, cognitive-behavioral } \\
\text { treatment }\end{array}$ & $\begin{array}{l}\text { Short term: } \\
\text { G2 more effective. } \\
\text { Long term: } \\
\text { G1 = G2 }\end{array}$ \\
\hline $\begin{array}{c}\text { Nicolakis et } \mathrm{al}^{24} \\
2002\end{array}$ & $\begin{array}{l}\text { Effectiveness of exercise } \\
\text { therapy in patients with } \\
\text { myofascial pain dysfunction } \\
\text { syndrome }\end{array}$ & 20 & $\begin{array}{l}\text { Massage, stretching, isometric } \\
\text { exercises, coordination } \\
\text { exercise, mobilization, } \\
\text { postural correction, breathing } \\
\text { with relaxation }\end{array}$ & Effective \\
\hline $\begin{array}{c}\text { De Laat et } \mathrm{al}^{5} \\
2003\end{array}$ & $\begin{array}{l}\text { Counseling and physical } \\
\text { therapy as treatment for } \\
\text { myofascial pain of the } \\
\text { masticatory system }\end{array}$ & 26 & $\begin{array}{c}\text { G1 - counseling }+ \text { G2 } \\
\text { G2 - massage and stretching }\end{array}$ & G1 and G2 were effective \\
\hline $\begin{array}{c}\text { Michelotti et } \mathrm{al}^{8} \\
2004\end{array}$ & $\begin{array}{l}\text { The additional value of a home } \\
\text { physical therapy regimen } \\
\text { versus patient education only } \\
\text { for the treatment of myofascial } \\
\text { pain of the jaw muscles: Short- } \\
\text { term results of a randomized } \\
\text { clinical trial }\end{array}$ & 70 & $\begin{array}{c}\text { G1 - counseling. } \\
\text { G2 - relaxation, massage, } \\
\text { stretching, coordination } \\
\text { exercises, diaphragmatic } \\
\text { breathing }\end{array}$ & $\begin{array}{c}\text { G2 was more effective } \\
\text { than G1 }\end{array}$ \\
\hline $\begin{array}{l}\text { Truelove et al }{ }^{14} \\
2006\end{array}$ & $\begin{array}{l}\text { The efficacy of traditional, } \\
\text { low-cost and non } \\
\text { splint therapies for } \\
\text { temporomandibular disorder: } \\
\text { A randomized controlled trial }\end{array}$ & 200 & $\begin{array}{c}\text { G1 - relaxation, passive } \\
\text { stretching } \\
\text { G2 - G1 + rigid oral appliance } \\
\text { G3 - G1 + soft oral appliance }\end{array}$ & $\begin{array}{l}\text { Results: Similar and effective } \\
\qquad \mathrm{G} 1=\mathrm{G} 2=\mathrm{G} 3\end{array}$ \\
\hline $\begin{array}{l}\text { Mulet et al20 } \\
2007\end{array}$ & $\begin{array}{l}\text { A randomized clinical trial } \\
\text { assessing the efficacy of } \\
\text { adding } 6 \times 6 \text { exercises to self- } \\
\text { care for the treatment of } \\
\text { masticatory myofascial pain }\end{array}$ & 45 & $\begin{array}{l}\text { G1 - counseling, relaxation } \\
\text { and stretching } \\
\text { G2 - G1 + } 6 \times 6 \text { exercise from } \\
\text { Rocabado }\end{array}$ & $\begin{array}{l}\text { Results: Similar and effective } \\
\qquad \mathrm{G} 1=\mathrm{G} 2\end{array}$ \\
\hline
\end{tabular}

* It was assessed the effectiveness regarding the decrease of pain and increase of mandibular movement amplitude. 
It should be noted that therapeutic exercises have been classified into different types for didactic purposes, only. Additionally, exercises are designed for groups of muscles, not for single muscles or isolated situations. For example, the contraction of a muscle group automatically causes its antagonists to stretch and vice versa.

Patient's awareness is also of great importance to achieve treatment success. Training the patient on how to do the exercises and checking if they have been performed correctly are measures that should be taken in order to reduce patient's errors and increase the likelihood of managing the TMD. ${ }^{9}$

Patients with breathing problems frequently report depression, fatigue and sleep disorders. As a consequence, they present alterations in pain sensitivity. ${ }^{15}$ Primary and accessory respiratory muscles usually contribute to craniofacial pain and associated symptoms in the cervical region. Therefore, they influence head posture. ${ }^{27}$

Some authors have considered body posture to be important in the diagnosis and prognosis of TMD, ${ }^{19,24}$ since postural exercises are also recommended to restore or optimize alignment of the craniomandibular system. ${ }^{18}$

Researches addressing the use of exercises to manage muscular DTM present some limitations which must be highlighted. Terms such as manual therapy, mobilization, manipulation and therapeutic exercises are too generic and may involve different forms of movement. Therefore, a detailed description of the techniques used is very important not only to allow study reproducibility, but also to confirm its results. ${ }^{18,28}$
Such description should include frequency, number of repetitions, intensity of performance, treatment period and manner of conducting the exercises. Moreover, the prescribed exercises are usually performed in conjunction with other therapies, making it difficult to verify the real effectiveness of the proposed exercise. Additionally, most studies do not have a control group, which leads one to question whether the exercise was really effective or if there was clinical relapse due to the natural course of the disease. ${ }^{8}$ Furthermore, several studies present a major flaw in terms of defining which subgroup of TMD was treated, thus, raising doubts about the effectiveness of the treatment prescribed. ${ }^{17}$ Likewise, the limited number of samples studied is not enough to yield significant conclusions regarding the recommended treatment, besides being usually based on empirical findings. ${ }^{3}$ However, since the majority of the exercise techniques used is based on clinical experience, one of the major limitations is the lack of randomized clinical trials based on standardized research criteria. ${ }^{29}$

The results of the present study demonstrate that the success of therapies that recommend the use of exercises in the treatment of muscular TMD is directly related to a correct diagnosis.

Additionally, although therapeutic exercises present a promising future in the control of TMD, further randomized studies should be carried out in order to provide more knowledge on how to prescribe such exercises (duration, frequency, etc.) and to access their actual efficacy in the different subtypes of TMD. 


\section{REFERENCES}

1. De Leeuw R, editor. Orofacial pain: Guidelines for assessment, Diagnosis, and management. 4th ed. Chicago: Quintessence; 2008. p. 129-58.

2. Sessle BJ, Lavigne GJ, Lund JP, Dubner R, editors. Orofacial pain: from basic science to clinical management. 2nd ed. Chicago: Quintessence; 2008. p. 179-85.

3. Carlsson GE, Magnusson T, Guimarães AS. Tratamento das disfunções temporomandibulares na clínica odontológica. São Paulo: Quintessence; 2006. p. 9-23.

4. Dworkin SF, LeResche L. Research diagnostic criteria for temporomandibular disorders: review, criteria, examinations and specifications, critique. J Craniomandib Disord. 1992;6(4):301-55.

5. De Laat A, Stappaerts K, Papy S. Counseling and physical therapy as treatment for myofascial pain of masticatory system. J Orofac Pain. 2003;17(1):42-9.

6. Greene CS. The etiology of temporomandibular disorders: Implications for treatment. J Orofac Pain. 2001:15(2):93-116.

7. Dworkin SF, Turner JA, Mancl L, Wilson L, Massoth D, Huggins KH, et al. A randomized clinical trial of a tailored comprehensive care treatment program for temporomandibular disorder. J Orofac Pain. 2002:16(4):259-76

8. Michelotti A, Steenks MH, Farella M, Parisini F, Cimino R, Martina R. The additional value of a home physical therapy regimen versus patient education only for the treatment of myofascial pain of the jaw muscles: short-term results of a randomized clinical Trial. J Orofac Pain. 2004;18(2):114-25

9. Michelotti A, De Wijer A, Steenks M, Farella M. Home exercises regimes for the management of non-specific temporomandibular disorders. J Oral Rehabil. 2005:32(11):779-85

10. Clark GT. Classification, causation and treatment of masticatory myogenous pain and dysfunction. Oral Maxillofac Surg Clin North Am. 2008;20:145-57.

11. Fricton JR, Ouyang W, Nixdorf DR, Schiffman EL, Velly AM, Look JO. Critical appraisal of methods used in randomized controlled trials of treatment for temporomandibular disorders. J Orofac Pain. 2010:24(2):139-51

12. Magnusson T, Syrén M. Therapeutic jaw exercises and interocclusal appliance therapy. Swed Dent J. 1999;23(1):27-37.

13. Medlicott MS, Harris SR. A systematic review of the effectiveness of exercise, manual therapy, electrotherapy, relaxation training, and biofeedback in the management of temporomandibular disorder. Phys Ther. 2006:86(7):955-73.

14. Truelove E, Huggins KH, Mancl L, Dworkin SF. The efficacy of traditional, low-cost and nonsplint therapies for temporomandibular disorder: a randomized controlled trial. J Am Dent Assoc. 2006:137(8):1099-107.
15. Carlson CR, Bertrand PM, Ehrlich AD, Maxwell AW, Burton RG. Physical self-regulation training for the management of temporomandibular disorders. J Orofac Pain. 2001;15(1):47-55.

16. Quinn JH. Mandibular exercises to control bruxism and deviation problems. J Craniomandibular Pract. 1995:13(1):30-4

17. Nicolakis P, Erdogmus B, Kopf A, Djaber-Ansari A, Piehslinger E, FialkaMoser $V$. Exercise therapy for craniomandibular disorders. Arch Phys Med Rehabil. 2000:81:1137-42.

18. McNeely ML, Armijo Olivo S, Magee DJ. A systematic review of the effectiveness of physical therapy interventions for temporomandibular disorders. Phys Ther. 2006;86(5):710-25.

19. Fricton J. Myogenous temporomandibular disorders: diagnostic and management considerations. Dent Clin North Am. 2007;51(1):61-83.

20. Mulet M, Decker KL, Look JO, Lenton PA, Schiffman EL. A randomized clinical trial assessing the efficacy of adding $6 \times 6$ exercises to selfcare for the treatment of masticatory myofascial pain. J Orofac Pain. 2007:21(4):318-28.

21. Marbach JJ. Temporomandibular pain and dysfunction syndrome History, physical examination, and treatment. Rheum Dis Clin North Am 1996:22(3):477-98.

22. Biasoli MC. Tratamento fisioterápico na terceira idade. Rev Bras Med. 2007:64(11 n. esp):62-8

23. Simons DG, Travell JG. Simons LS. Dor e disfunção miofascial. Manual dos pontos de gatilho, volume I - Parte superior do corpo. 2 ed. São Paulo: Artmed; 2005. p. 91-152.

24. Nicolakis P, Erdogmus B, Kopf A, Nicolakis M, Piehslinger E, Fialka-Moser $\checkmark$. Effectiveness of exercise therapy in patients with myofascial pain dysfunction syndrome. J Oral Rehabil. 2002;29(4):362-8.

25. Santiesteban J. Isometric exercises and a simple appliance for temporomandibular joint disfunction: a case Report. Phys Ther 1989;69(6):463-6.

26. Van Selms MKA, Lobbezoo F, Naeije M. Time courses of myofascial temporomandibular disorder complaints during a 12-month follow-up period. J Orofac Pain. 2009:23(4):345-52.

27. Hruska RJ. Influences of dysfunctional respiratory mechanics on orofacial pain. Dent Clin North Am. 1997:41(2):211-21.

28. Maluf AS, Moreno BGD, Alfredo PP, Marques AP, Rodrigues G. Exercícios terapêuticos nas desordens temporomandibulares uma revisão da literatura. Fisioter Pesq. 2008;15(4):408-15.

29. La Touche R, Fernandez-de-las-Penas C, Fernandez-Carnero J, Escalante K, Angulo-diaz-parreno S, Paris-Alemany A, et al. The effects of manual therapy and exercise directed at the cervical spine on pain and pressure pain sensitivity in patients with myofascial temporomandibular disorders. J Oral Rehabil. 2009;36(9):644-52. 